\title{
THE DETECTION OF ANTIBODIES TO SPERMATOZOA AND TO BLOOD GROUP ANTIGENS IN CERVICAL MUCUS
}

\author{
W. E. PARISH, J. A. CARRON-BROWN AND C. B. RICHARDS \\ Lister Institute of Preventive Medicine, London, Norwich Hospitals, and \\ School of Veterinary Medicine, University of Cambridge \\ (Received 5th August 1966, revised 24th November 1966)
}

\begin{abstract}
Summary. Extracts of cervical mucus taken during the non-menstrual interval contained $\gamma$-globulin and several other serum proteins. Natural agglutinating antibodies to the $\mathrm{A}$ and $\mathrm{B}$ blood group antigens were present in many samples, and immune-type, haemolytic anti-A and anti-B in six out of twelve selected individuals. Antibodies to Escherichia coli and Candida albicans were also detected.

In a search for evidence of local antibody formation in the genital tract without systemic stimulation, antibody present in cervical mucus but absent from the serum was found in eleven women; two had immune-type anti-A and one had immune-type anti-B; five had antibody to H25 flagellar antigen of Escherichia coli; and three had antibody cytotoxic to spermatozoa.
\end{abstract}

Earlier reports were confirmed that spermatozoa acquired the A or B antigen from the seminal plasma of individuals secreting the antigen. The antigens from spermatozoa of non-secretors were weak or absent. It was demonstrated that spermatozoa from a group A non-secretor and from a group $\mathrm{O}$ individual acquired the $\mathrm{A}$ antigen when incubated in seminal plasma from a group A secretor. Spermatozoa coated naturally with the $A$ antigen were unharmed when tested with immune-type anti-A sera capable of lysing group A red cells, though the antibody reacted with the spermatozoa.

A complement dependent antibody cytotoxic to spermatozoa of any $\mathrm{ABO}$ blood group was found in the cervical mucus of three women. In the one sample tested it separated with the $7 \mathrm{~S} \gamma$-globulin fraction. The antibody was specific for the spermatozoal head as detected by mixed cell antiglobulin and by immunofluorescence tests; and could be adsorbed out by group $\mathrm{O}$ spermatozoa. It was distinct from antinuclear factor.

\section{INTRODUCTION}

One cause of infertility in women in whom routine investigations reveal no abnormality may be allergy to spermatozoa. Married women are continually exposed to semen which contains foreign antigens. The seminal plasma contains the A or B antigens in men who are secretors of the antigens (Hartmann, 
1941) and these coat the surface of the spermatozoa (Edwards, Ferguson \& Coombs, 1964; Boettcher, 1965). Spermatozoa also have organ specific antigens which may stimulate auto-antibodies in the male (Rümke \& Hellinga, 1959; Cruickshank \& Stuart-Smith, 1959; Nakabayashi, Tyler \& Tyler, 1961; Phadke \& Padukone, 1964) and though some of these antigens are also acquired from the seminal plasma which firmly and completely covers the surface (Rümke \& Hellinga, 1959; Weil \& Rodenburg, 1960), human spermatozoa have antigens that are not present in the prostatic secretions (Rao \& Sadri, 1959).

Spermatozoal agglutinating antibodies have been found in the sera of women (Southam, 1963; Franklin \& Dukes, 1964a, b) and their presence has been correlated with unexplained infertility even though they have not been established as the cause (Franklin \& Dukes, 1964b), but the significance of these antibodies as evidence of allergic infertility is doubtful because they occur in the sera of women and men proved to be fertile at the time of their detection (Southam, 1963; Phadke \& Padukone, 1964). Moreover injection of experimental animals with spermatozoa stimulates formation of antibodies, but only in half of the experiments reviewed has any antifertility effect been reported (Tyler, 1961) though it is claimed that women injected with human spermatozoa become temporarily infertile (Baskin, 1932; Escuder, 1936; RodriquezLópez, 1936). In two investigations (Baskin, 1932; Escuder, 1936) the cervical secretion in about half of the women injected with human semen contained a factor cytotoxic for spermatozoa.

To test the possibility that antibodies cytotoxic for spermatozoa may cause infertility in women, it was decided to examine the extracts of cervical mucus to detect antibody formed locally in the genital tract in the absence of systemic stimulation, especially as any cytotoxic effect would be confined to the tract.

The cervical mucus and, where possible, the serum of patients attending the clinic for infertility at Addenbrooke's Hospital, Cambridge, was examined for antibodies to the A and B blood group antigens, bacteria and spermatozoa. Antibody in the cervical mucus which was absent from the serum indicated local formation in the genital tract, as was found in two women of blood group $\mathrm{O}$ with an immune-type anti-A and another with an immune-type anti-B antibody, five women with an antibody to a flagellar antigen of Escherichia coli, and three with an antibody cytotoxic to spermatozoa.

The presence on spermatozoa of A or B antigens derived from the seminal plasma was confirmed, and the possible cytotoxic effect of immune-type antibodies was tested to determine whether an $\mathrm{ABO}$ incompatibility would result in damage to the spermatozoa.

\section{MATERIALS AND METHODS}

\section{Material}

Cervical mucus was aspirated with a hypodermic syringe into sterile flexible polythene tubing of known diameter, and its volume estimated from the length of the column. The material was then ejected into 1 or 2 vol. of warm Dale's Ringer solution or Gey's saline containing 100 i.u. penicillin and $50 \mu \mathrm{g}$ 
streptomycin/ml, to give a dilution of $1: 2$ or $1: 3$. This was incubated for $1 \mathrm{hr}$ at $37^{\circ} \mathrm{C}$ and was centrifuged to obtain a clear supernatant fluid. It was sometimes frozen for storage until used. Occasionally vaginal pipettes were used to collect the samples but the volume obtained was smaller, often too small to be used.

Spermatozoa were separated from the seminal plasma by centrifuging at about $2000 \mathrm{rev} / \mathrm{min}$ in a bench-type M.S.E. centrifuge for $10 \mathrm{~min}$, and the supernatant fluid removed. The cells were then resuspended in a small volume of Dale's Ringer solution in a siliconed tube and left standing at $4^{\circ} \mathrm{C}$ for about $1 \mathrm{hr}$, during which time the heavier clumps of cellular debris precipitated, leaving spermatozoa and some mononuclear cells in the supernatant fluid which was drawn off. The cells of the supernatant fluid were washed twice in the balanced salt solution containing $0.5 \%$ bovine plasma albumin (Armour, crystalline) and then resuspended in the volumes required for the tests. The final suspension contained $5 \times 10^{4}$ to $3 \times 10^{6}$ spermatozoa $/ \mathrm{ml}$, of which 70 to $80 \%$ were motile, depending upon the quality of the sample.

\section{Double diffusion gel plate precipitation tests and immunoelectrophoresis}

Seven millilitres of $1.5 \%$ agar in phosphate buffered saline $(\mathrm{pH} \mathrm{7)}$ containing $0.1 \%$ sodium azide was poured onto lantern slides $31 \times 3 \frac{1}{4}$ in. Four sets of six peripheral basins with one central basin were cut in the gel, each basin being $5 \mathrm{~mm}$ diameter and $7 \mathrm{~mm}$ apart. After the reagents were added the plates were left overnight in a humid atmosphere for precipitation to develop and were then washed free of unprecipitated protein, dried and stained with Amido Schwarz. Readings were made after overnight precipitation, and again after staining.

For immunoelectrophoresis, $1.5 \%$ agar gels were prepared in barbitone buffer $\mathrm{pH} 8 \cdot 6, I=0 \cdot 05$, on similar plates and a constant voltage of 150 applied for $1 \mathrm{hr}$. Lateral troughs cut $4 \mathrm{~mm}$ each side of the basins were filled with rabbit antibody to human serum proteins, and precipitation left to develop as above.

\section{Detection of anti- $A$ and anti- $B$ antibody}

In the initial tests to determine the incidence of natural anti-A and anti-B agglutinating antibodies, one drop of a $2 \%$ suspension of washed $\mathrm{A} 1, \mathrm{~B}$ or $\mathrm{O}$ red cells was each added to one drop (approximately $0.03 \mathrm{ml}$ ) of cervical mucus extract in small tubes $5 \mathrm{~mm}$ diameter $\times 50 \mathrm{~mm}$ length and left to settle at room temperature. Any extract that agglutinated the A or B cells was tested for haemolysis by mixing $0.1 \mathrm{ml}$ of $A$ or $B$ red cells and $0.1 \mathrm{ml}$ of human group $\mathrm{AB}$ serum as a source of complement in tubes $7 \mathrm{~mm}$ diameter $\times 50 \mathrm{~mm}$ length. After incubation at $37^{\circ} \mathrm{C}$ for $30 \mathrm{~min}$ the mixture was gently centrifuged to reveal any lysis. Sera were tested in a similar manner, but were always titrated, and, in the lytic tests, were used unheated without the addition of extra complement.

In the more critical tests (Tables 3 and 4) a bulk titration of two-fold dilutions was prepared and distributed in $0.01 \mathrm{ml}$ volumes to the required number of rows of small tubes. Washed red cells in $3 \%$ suspension were added to each tube, and were left to settle at $4^{\circ} \mathrm{C}$ or at $37^{\circ} \mathrm{C}$ to detect agglutination. 
Tests for antibody cytotoxic for spermatozoa

A $0.1 \mathrm{ml}$ volume of a suspension of living spermatozoa at a concentration of approximately $2 \times 10^{5} / \mathrm{ml}$ was added to $0.1 \mathrm{ml}$ of the cervical mucus extract, or serum, and $0.1 \mathrm{ml}$ of human group $\mathrm{AB}$ serum as a source of complement in a siliconed tube and incubated at $37^{\circ} \mathrm{C}$. Drops were removed at intervals and examined on sealed siliconed glass slides by phase contrast microscopy. In some tests drops of the spermatozoa, test extract and human complement were mixed together between a siliconed slide and coverslip, sealed with wax and incubated.

\section{Mixed cell antiglobulin tests}

The technique was that of Chalmers, Coombs, Gurner \& Dausset (1959) and used for similar tests on spermatozoa by Edwards et al. (1964) to detect the fixation of specific antibody on the cell surface.

The principle of the test is that cells exposed to specific antibody fix it to their surface and all non-attached serum proteins may be washed off. Red cells sensitized with a non-agglutinating antibody, e.g. rhesus positive $\mathrm{D}$ cells sensitized by incomplete anti-D, are added together with a rabbit anti-human globulin serum and gently centrifuged. If the test cells, in this instance spermatozoa, have fixed specific antibody on their surface, the antiglobulin serum causes the indicator red cells to adhere to the spermatozoa. If no antibody has reacted with the spermatozoa the sensitized red cells fail to adhere to them.

\section{Immunofuorescence tests}

The principle of the immunofluorescence technique resembles that of the antiglobulin test, except that specific antibody attached to the cell surface is detected by a rabbit anti-human globulin serum labelled with fluorescein isothiocyanate, which glows green when viewed under ultra-violet light.

The fluorescein labelled rabbit anti-human $\gamma$-globulin was adsorbed with powdered human skin, washed $\mathrm{AB}$ red cells, and also by washed spermatozoa though this proved unnecessary. The antiserum reacted only with cells coated with globulin; the reaction was strong with IgG globulin and weak with IgM. The suspension of washed spermatozoa was treated with an equal volume $(0.05$ or $0.1 \mathrm{ml})$ of cervical mucus extract or serum for $30 \mathrm{~min}$ at $37^{\circ} \mathrm{C}$, washed three times in $0.5 \mathrm{ml}$ diluent and resuspended in $0.1 \mathrm{ml}$; to this was added $0.1 \mathrm{ml}$ of the $\gamma$-globulin fraction of a fluorescein labelled rabbit anti-human $\gamma$-globulin and the mixture incubated for $30 \mathrm{~min}$. The cells were then washed three times and mounted on slides in $90 \%$ glycerol with $10 \%$ phosphate buffer at $\mathrm{pH} 7 \cdot 8$. They were examined under ultraviolet light on a Reichert Zetopan microscope with a dark ground condenser, using excitor filter E2 (UG $1 / 1.5 \mathrm{~mm}$ ) and absorption filter Sp $2($ GG $13 / 3 \times 1 \mathrm{~mm})$ Wratten 2B.

\section{RESULTS}

Detection of globulins in cervical mucus

Saline extracts of cervical or vaginal mucus examined by immunoelectrophoresis contained $\gamma$-globulin, transferrin and albumin. Other serum proteins 
were sometimes detected depending upon the concentration of the extract (Pl. 1, Fig. 1). When a pool of extracts of cervical mucus was concentrated six times and separated on a sucrose gradient by a Spinco preparative ultracentrifuge, weak concentrations of $\gamma$-globulin were found in the 7S range, and also $\beta$-globulin.

One extract of vaginal mucus (well 6, P1. 1, Fig. 1) contained a slow-moving $\gamma$-globulin that appeared to be a hydrolytic fragment similar to the slow fragment of papain digested $\gamma$-globulin. This was confirmed in a double-diffusion gel precipitation test where it gave a reaction of identity with papain-digested human $\gamma$-globulin (Pl. 1, Fig. 2). By the same test it was also found that some samples of vaginal mucus taken during the inter-menstrual part of the cycle contained several serum proteins.

TABLE 1

DETECTION OF HAEMAGGLUTINATING ANTIBODY IN THE CERVICAL MUCUS OF 102 WOMEN WITH A NORMAL UROGENITAL TRACT, FROM WHOM ONE SAMPLE OF MUCUS WAS TAKEN

\begin{tabular}{c|c|l}
\hline Blood group & No. of subjects & \multicolumn{1}{|c}{$\begin{array}{c}\text { No. with } \\
\text { isohaemagglutinin }\end{array}$} \\
\hline A & 39 & Anti-B,6 \\
B & 10 & anti-A,3 \\
AB & 4 & None \\
O & 49 & Anti-A only, 8; anti-A and anti-B, 3 \\
Total & 102 & 20 \\
\hline
\end{tabular}

TABLE 2

DETECTION OF HAEMAGGLUTINATING ANTIBODY IN THE CERVICAL MUCUS OF TWENTY-EIGHT WOMEN FROM WHOM TWO OR THREE SAMPLES WERE TAKEN AND POOLED

\begin{tabular}{c|c|l}
\hline Blood group & No. of subjects & \multicolumn{1}{|c}{$\begin{array}{c}\text { No. with } \\
\text { isohaemagglutinin }\end{array}$} \\
\hline A & 11 & Anti-B, 4 \\
B & 4 & Anti-A, 1 \\
AB & 1 & None \\
O & 12 & Anti-A only, 4*; anti-A and anti-B, 4 \\
Total & 28 & 13 \\
\hline
\end{tabular}

* One of these samples of anti-A had the properties of an immune antibody.

Antibodies in cervical mucus to $A$ and $B$ blood group antigens and to bacteria

Haemagglutinating antibody was found in cervical mucus in twenty of 102 subjects from whom one sample was taken. Samples from women of blood group $O$ contained anti-A more frequently than both anti-A and anti-B together: no sample from a group $\mathrm{O}$ individual contained anti-B only (Table 1 ).

When two or three samples from each individual were pooled before testing, thirteen out of twenty-eight contained haemagglutinins (Table 2). As in the 
tests of single samples group $O$ individuals were not found to have anti-B in the cervical mucus unless it was accompanied by anti-A.

A further fourteen samples, taken consecutively at one clinic, were tested for anti-A and anti-B antibody and titrated when sufficient material was available. No antibody was found in seven. Of the remaining seven, four contained both anti-A and anti-B, and three contained anti-A although in two samples it was only just detectable. The titres of agglutination of red cells by the naturally occurring antibody in three of the samples at $4^{\circ} \mathrm{C}$ and at $37^{\circ} \mathrm{C}$ are presented in Table 3.

The anti-A in one sample had properties of an immune-type antibody (Table 2). It lysed Al red cells in the presence of human complement and had a higher agglutination titre at $37^{\circ} \mathrm{C}(1: 128)$ than at $4^{\circ} \mathrm{C}(1: 32)$. This discovery stimulated further search for immune-type antibodies in cervical mucus of twelve women of blood group O. Four of the women were known to have a haemolytic antibody in their serum. The sera and cervical mucus extracts were tested for their ability to agglutinate A1, A2 or B red cells at a higher titre at

TABle 3

AGGLUTINATION TITRES OF NATURALLY OCCURRING ANTIBODY IN CERVICAL MUCUS TO GROUP A OR B RED CELLS

\begin{tabular}{l|ccc|ccc}
\hline & \multicolumn{3}{|c|}{$4^{\circ} C$} & \multicolumn{3}{|c}{$37^{\circ} C$} \\
\cline { 2 - 7 } & Group A1 & Group A2 & Group B & Group A1 & Group A2 & Group B \\
\hline 1 & 48 & 12 & 96 & 96 & 12 & 96 \\
2 & 24 & 3 & 6 & 12 & 3 & 6 \\
3 & 12 & $\mathrm{Nt}$ & $<2$ & 24 & $\mathrm{Nt}$ & $<2$ \\
\hline
\end{tabular}

Nt, No test made.

Titres presented as reciprocals of dilutions.

$37^{\circ} \mathrm{C}$ than at $4^{\circ} \mathrm{C}$; for susceptibility of partial removal of agglutinins for human A red cells by adsorption with pig group A red cells, and for their ability to lyse red cells in the presence of human complement. These are properties of immune-type antibodies (Mollison, 1961). They were also treated with 2-mercaptoethanol, which destroys the activity of $19 \mathrm{~S}$ antibodies, to determine how much of the antibody activity was due to this class of immunoglobulin.

In four of the twelve selected women no immune-type antibody was found in the sera or cervical mucus. Immune anti-A was present in both serum and cervical mucus of two, and in the serum only of two others. One woman had immune anti-B in both serum and cervical mucus. Of greater interest was the discovery of immune anti-A in the cervical mucus of two women which was not present in the serum. In another woman immune anti-B was present in the cervical mucus, though in low concentration, but the serum contained immune anti-A only. The results of the tests on sera and cervical mucus of three samples containing immune-type antibody in the cervical mucus are presented in Table 4. 
Treatment of four samples of cervical mucus containing immune-type antibody with 2-mercaptoethanol abolished the haemolytic property and decreased the agglutination titres, though agglutination of $\mathrm{Al}$ cells by three samples and $\mathrm{B}$ cells by one was still at least as strong at $37^{\circ} \mathrm{C}$ as at $4^{\circ} \mathrm{C}$.

Antibody to one or more of four different $\mathrm{O}$ groups of Escherichia coli was present in the cervical mucus of six of sixteen patients, with titres of $1: 2$ to $1: 8$, but was also present in the sera in higher concentrations.

In five women, antibody to the flagella $\mathrm{H} 25$ antigen was present in the cervical mucus in titres of $1: 4,1: 8,1: 8,1: 32$ and $1: 32$, without being detectable in the corresponding sera.

TABLE 4

AGGLUTINATION AND COMPLEMENT FIXATION TITRES OF ANTI-A AND ANTI-B ANTIBODIES IN SERUM AND CERVIGAL MUCUS OF THREE WOMEN OF BLOOD GROUP O

\begin{tabular}{|c|c|c|c|c|c|c|c|c|}
\hline \multirow[b]{2}{*}{ Group } & \multicolumn{2}{|c|}{ Serum } & \multirow[b]{2}{*}{ C.f.t. } & \multicolumn{4}{|c|}{ Cervical mucus } & \multirow[b]{2}{*}{ Significance } \\
\hline & \multicolumn{2}{|c|}{$\begin{array}{l}\text { Agglutination } \\
4^{\circ} \mathrm{C} \quad 37^{\circ} \mathrm{C}\end{array}$} & & \multicolumn{2}{|c|}{$\begin{array}{l}\text { Agglutination } \\
4^{\circ} \mathrm{C} \quad 37^{\circ} \mathrm{C}\end{array}$} & C.f.t. & $\begin{array}{l}\text { Agglutination after } \\
2-\text { mercaptoethanol } \\
4^{\circ} \mathrm{C} \quad 37^{\circ} \mathrm{C}\end{array}$ & \\
\hline Al & 1024 & 2048 & 16 & 16 & 16 & N.F. & \multirow[b]{2}{*}{ Not tested } & Immune anti-A \\
\hline $\begin{array}{l}\mathrm{A} 2 \\
\mathrm{~B}\end{array}$ & $\begin{array}{r}512 \\
8\end{array}$ & $\begin{array}{r}1024 \\
8\end{array}$ & N.F. & $\begin{array}{r}8 \\
128\end{array}$ & $\begin{array}{r}8 \\
256\end{array}$ & 2 & & $\begin{array}{l}\text { Immune anti-B } \\
\text { in mucus }\end{array}$ \\
\hline Al & 32 & 8 & N.F. & 64 & $128 * a$ & 4 & \multirow[b]{2}{*}{ Not tested } & Immune anti-A \\
\hline$\stackrel{\mathrm{A} 2}{\mathrm{~B}}$ & $\begin{array}{r}8 \\
16\end{array}$ & $\begin{array}{l}2 \\
8\end{array}$ & N.F. & $\begin{array}{r}32 \\
8\end{array}$ & $\begin{array}{r}64 \\
4\end{array}$ & N.F. & & \\
\hline A1 & 16 & 2 & N.F. & 64 & $64 * b$ & 2 & 16 & Immune anti-A \\
\hline $\begin{array}{l}\mathrm{A} 2 \\
\mathrm{~B}\end{array}$ & $\begin{array}{r}2 \\
32\end{array}$ & N.A. & N.F. & $\begin{array}{r}16 \\
8\end{array}$ & $\begin{array}{r}32 \\
4\end{array}$ & N.F. & $\begin{array}{l}3 \\
1\end{array}$ & \\
\hline
\end{tabular}

C.f.t., Complement fixation titre; N.A., no agglutination; N.F., none fixed;

* Partially removed by adsorption with pig group A cells with residual titres, a 32, b 8 . Titres presented as reciprocals of the dilutions.

Agglutinating antibody to Candida albicans (titres about 1:8) was found in the mucus of five of the sixteen patients, and was also present in higher concentrations in the serum.

Blood group antigens on spermatozoa and failure of immune anti-A or anti-B antibody to be cytotoxic

Blood group A or B antigens were detected on washed spermatozoa from men who had the same antigen on their red cells when the individual was a secretor; that is, the seminal fluid contained the soluble antigen.

In a few instances the $\mathrm{A}$ antigen was detected by direct agglutination of the washed spermatozoa when human immune anti-A antibody was added to the suspension. 
In all samples from secretor individuals the antigen was revealed by the mixed cell antiglobulin reaction (similar to that depicted in Pl. 2, Figs. 8 and 9 ). The antigen was present on both the heads and tails. There was no nonspecific fixation of globulin by spermatozoa exposed to the unrelated antibody, e.g. group A spermatozoa treated with anti-B, and no uptake of globulin by group $\mathrm{O}$ spermatozoa treated with anti-A and anti-B.

Spermatozoa from non-secretor individuals without the A or B antigen in the seminal fluid reacted very weakly in two tests (group A) and no reaction in two other tests (one group A and one B). Some of these results are presented in Table 5, where they were used as control tests in the detection of cytotoxic antibody.

These results indicated that the A or B antigen was acquired from the seminal fluid. The possibility that antigen can be acquired in this way was tested by adding washed spermatozoa from a group $\mathrm{A}$, non-secretor, and a group $\mathrm{O}$ individual to the cell-free seminal fluid of a group Al secretor, and incubating

TABLE 5

DETECTION OF SPECIFIC UPTAKE OF ANTIBODY BY SPERMATOZOA FROM A GROUP A NON-SEGRETOR AND A GROUP O INDIVIDUAL BY THE MIXED GELL ANTIGLOBULIN TECHNIQUE

\begin{tabular}{l|c|cc}
\hline \multicolumn{1}{c|}{ Test } & No. of samples & \multicolumn{2}{|c}{ Agglutination to spermatozoa } \\
\cline { 2 - 3 } & & $\begin{array}{c}\text { A } \\
\text { non-secretor }\end{array}$ \\
\hline Natural anti-A serum & 1 & - & - \\
Immune anti-A serum & 2 & $(+)$ & - \\
Group AB serum & 1 & - & +++ \\
Cytotoxic cervical mucus extract & 3 & ++ & - \\
Sera from patients with cytotoxic cervical mucus & 3 & - & - \\
Non-cytotoxic cervical mucus extract & 8 & - & - \\
\hline
\end{tabular}

Scale of degree of agglutination of the sensitized red cells to the spermatozoa: - , none; $(+)$, very weak; +++ , strong.

them for $3 \mathrm{hr}$ at $37^{\circ} \mathrm{C}$. The spermatozoa were then washed three times and tested by the antiglobulin method.

The spermatozoa from the group Al non-secretor reacted weakly in the antiglobulin test before exposure to the seminal fluid, and spermatozoa from a group $\mathrm{O}$ donor gave no reaction. After exposure to the seminal fluid of the group A secretor, spermatozoa from both individuals reacted very strongly in the antiglobulin tests and were completely covered by agglutinated red cells.

Immune anti-A antibody proved to have no cytotoxic effects on spermatozoa carrying the A antigen. Spermatozoa from three group A secretor men were tested with each of three immune anti-A sera in the presence of added human complement. The immune anti-A sera had haemolytic titres of $1: 16$ to $1: 32$ for an equal volume of a $2 \%$ suspension of human $\mathrm{A}$ red cells incubated at $37^{\circ} \mathrm{C}$ for $30 \mathrm{~min}$.

There was no cytotoxic effect on the spermatozoa in the immune anti-A sera; as many remained motile after $30 \mathrm{~min}$ to approximately $12 \mathrm{hr}$ as in the 


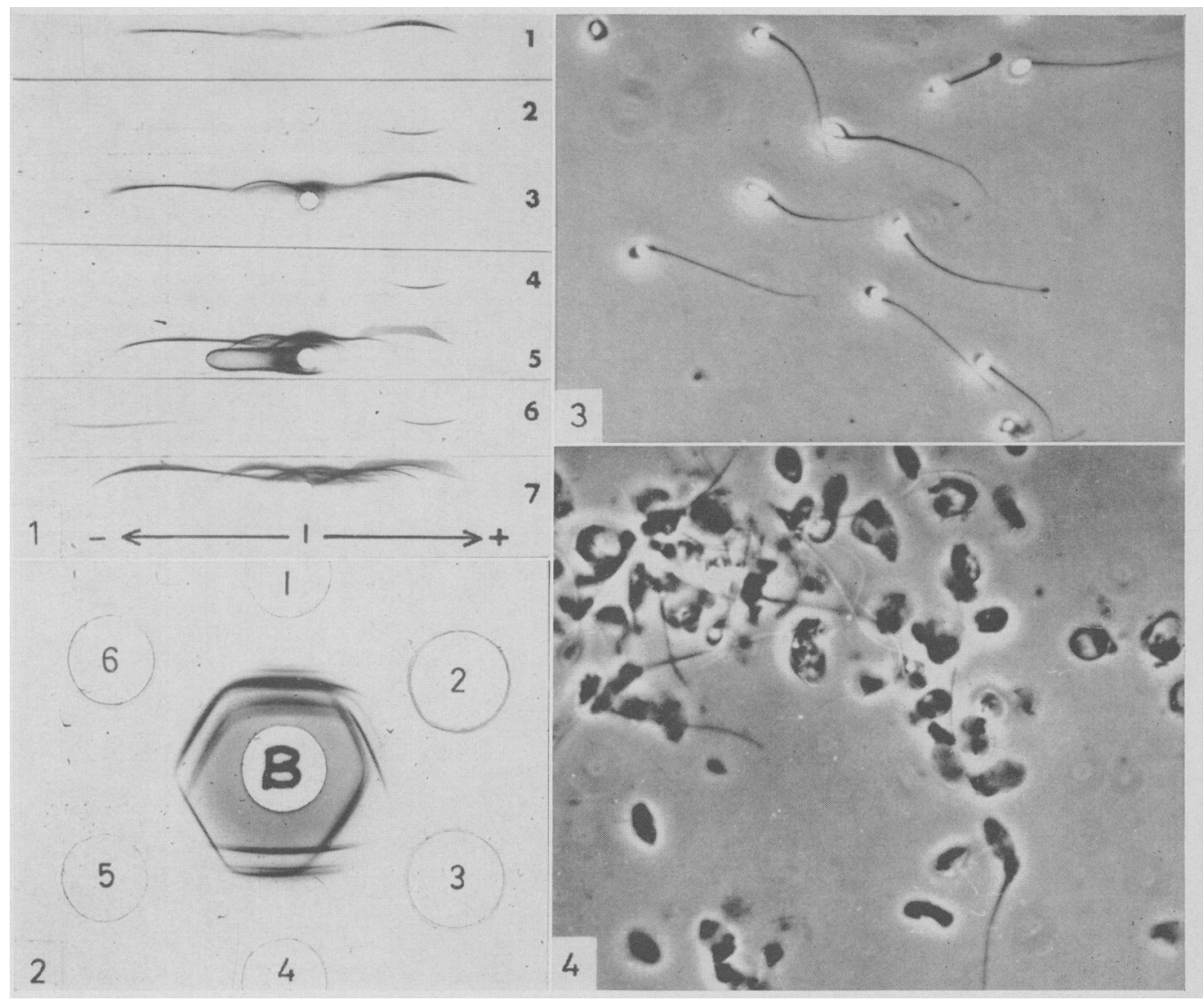

Fig. 1. Immuno-elcctrophoresis in agar gel. Wells 1,2 and 4 contained cervical mucus; 3,5 and 6 vaginal mucus. Well 7 contained human serum diluted 1 in 3 . Precipitation lines produced by rabbit anti-human serum in the troughs. The extract in well 6 contained a slow $\gamma$-globulin.

FIG. 2. Ouchterlony double diffusion precipitin gel-plate test. Centre well B contained rabbit anti-human serum. Peripheral wells; I, human serum; 2, vaginal mucus; 3 , papain digested human $\gamma$-globulin; 4 , human serum; 5 , human $\gamma$-globulin; 6 , vaginal mucus.

Vaginal mucus, well 2, contained a slow $\gamma$-globulin component which gave a line of identity with papain-digested human $\gamma$-globulin in well 3.

Fig. 3. Spermatozoa. Control test in normal cervical mucus extract plus complement for 2 hr. Phase contrast, about $\times 430$.

Fig. 4. Enlarged heads of spermatozoa 40 min after exposure to cytotoxic antibody and human complement. Some are pale and have shed their tails, others are granular or amorphous. A few spermatozoa of normal size remain in the large group. Phase contrast, about $\times 530$. 
PI.TTE 2
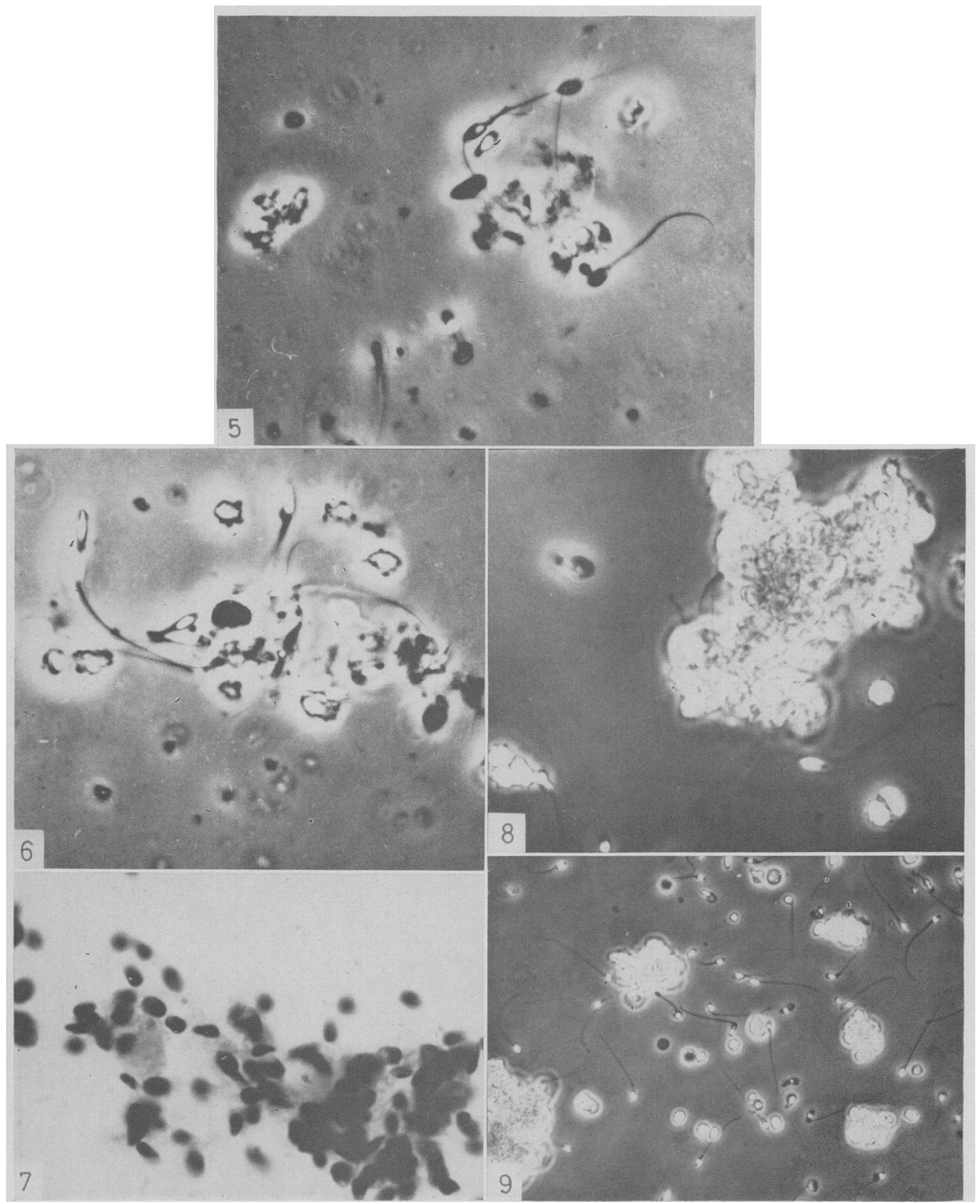

(Fuing f). 477) 
normal human sera controls. Indeed more cells survived in these sera than those left for the same time in the original seminal plasma.

\section{Characteristics of antibody in cervical mucus cytotoxic for spermatozoa}

In tests of cervical mucus from forty-eight patients attending the clinic for infertility, a factor cytotoxic to spermatozoa was present in four; in three of these the factor appeared to be a complement dependent antibody specific for spermatozoa.

Incubation of $0.1 \mathrm{ml}$ volumes of the cervical mucus extract from four of the patients, human complement and living spermatozoa resulted in cytotoxic changes commencing in about $10 \mathrm{~min}$ and continuing for approximately $2 \mathrm{hr}$. Most of the spermatozoa in a normal sample moved in the same direction in waves across the slide (Pl. 1, Fig. 3). Within 10 to $20 \mathrm{~min}$ of exposure to the cytotoxic antibody they wandered aimlessly, and movement ceased in the majority in 30 to $40 \mathrm{~min}$. Immobilization occurred before cytotoxic changes were observed. In the majority of the cells that were living at the start of the test the head enlarged and became pale (Pl. 1, Fig. 4); some showed no further change, but in others finely granular material surrounded the head and probably exuded from it (Pl. 2, Fig. 5), finally leaving shrivelled or fragmented heads, often severed from the tails, with granular material adherent to the surface (P1. 2, Fig. 6). As these changes could be observed in washed suspensions of spermatozoa relatively free from seminal debris, the increased amount of granular material is believed to result from damage to the sperm head, but though the heads shrivelled it was not possible to observe passage of material from them. Spermatozoa that were non-motile at the beginning of the test were unchanged. In the absence of normal serum the same cervical mucus extracts immobilized about $8 \%$ of the spermatozoa in $10 \mathrm{~min}$, without any subsequent cytotoxic degeneration.

The antibody was equally cytotoxic to spermatozoa from individuals of blood group A secretor, A non-secretor, B (secretor status unknown) and O. Furthermore, they were equally cytotoxic for the spermatozoa suspended in their own seminal plasma after liquefaction, or as washed cells resuspended in balanced salt solution containing $0.5 \%$ bovine plasma albumin.

\section{EXPLANATION OF PLATE 2}

FIG. 5. Finely granular material, possibly derived from the damaged spermatozoa, surrounding the heads $1 \mathrm{hr}$ after addition of cytotoxic antibody in cervical mucus extract with human complement. Intact spermatozoa were dead at the start of the test. Phase contrast, about $\times 530$.

Fig. 6. Enlarged spermatozoal heads, shrivelled heads with granular material on their surface, and heads of normal size after $2 \mathrm{hr}$ incubation in cervical mucus extract containing cytotoxic antibody, with human complement. Phase contrast, about $\times 530$.

Fig. 7. Two macrophages after ingesting spermatozoa killed by cytotoxic antibody. The nucleus of the cell on the left is still visible, but the cell on the right is laden with spermatozoa. Haematoxylin and eosin, about $\times 430$.

Fig. 8. Mixed antiglobulin positive test. Spermatozoa which have taken up the cytotoxic antibody on the head are covered by the agglutinated sensitized indicator red cells leaving a few tails protruding. On the left, three red cells are attached to a spermatozoal head. Phase contrast, about $\times 530$.

Fic. 9. Mixed cell antiglobulin negative test. Red cells are agglutinated in clumps separate from the spermatozoa which have not fixed globulin on their surface from normal cervical mucus. Phase contrast, about $\times 160$. 
To test whether the cytotoxic antibody was specific for spermatozoa, or whether it affected other cells of the genital tract, a drop of the extract and one drop of spermatozoal suspension were added to monolayers of macrophages obtained from human tonsils or from cervical mucus, and to polymorphonuclear neutrophils obtained from peripheral blood. The mixture had no adverse effect on the leucocytes, but on the addition of one drop of $1 / 10$ normal human serum, the spermatozoa immobilized by three of the four cervical mucus extracts were ingested by some of the phagocytic cells. Some macrophages became so laden with the dead spermatozoa that even the nuclei were obscured (Pl. 2, Fig. 7). With the remaining extract the spermatozoa, though immobilized, were not ingested; many of the macrophages became vacuolated and the neutrophils shed some of their granules and separated from the glass. This sample evidently contained no antibody specific for spermatozoa.

Further evidence that the cytotoxic factor was an antibody was obtained by mixed-cell antiglobulin and immunofluorescence tests.

In the mixed antiglobulin tests, washed spermatozoa from a group A nonsecretor and a group $\mathrm{O}$ individual were treated with sera or extracts of cervical mucus (Table 5) and tested for fixed globulin.

Fixed globulin was detected by adherence of large numbers of the indicator red cells to the spermatozoa which were treated with each of the three samples of cervical mucus extracts containing cytotoxic antibody (Pl. 2, Fig. 8). The reaction was confined to the heads. There was no adherence of red cells to spermatozoa treated with immune anti-A sera, sera from the three patients, or cervical mucus from eight women containing no cytotoxic antibody (Pl. 2, Fig. 9). No non-specific fixation occurred in control samples.

The same extracts of cervical mucus and sera (Table 5) were also tested by the immunofluorescence technique. Only the three cervical mucus extracts containing the cytotoxic antibody reacted with the spermatozoa of both $\mathrm{A}$ and O blood groups. As before, the reaction was confined to the head which fluoresced bright green, though occasionally there was weak staining of the body. The tail never stained. Spermatozoa exposed to the corresponding sera or to other extracts of cervical mucus did not take up the fluorescein labelled antiglobulin and exhibited only a dull brown or red-purple autofluorescence of parts of the head and the tail. Some of the granular debris fluoresced weakly, possibly due to non-specific adsorption by small particles. The technique was a little less sensitive than the mixed cell antiglobulin test as it did not reveal the weak reaction between the group A non-secretor spermatozoa treated with immune anti-A antibody.

The cytotoxic antibody in the three samples of cervical mucus was taken up neither by the lymphocytes present in the suspension of spermatozoa, nor by sections of fresh human skin, though the sections of skin were capable of fixing antinuclear factors which could be detected by the fluorescein-labelled antiglobulin. There was enough of one of the three extracts for an adsorption test; two adsorptions with a suspension of group $\mathrm{O}$ spermatozoa almost completely removed the antibody.

In one extract fractionated on a sucrose gradient by ultracentrifugation, the cytotoxic antibody separated with the $7 \mathrm{~S} \gamma$-globulin. 


\section{DISCUSSION}

Before the search was made in cervical mucus for antibodies cytotoxic to spermatozoa, mucus was first examined for globulin and for antibodies to the $A$ and $B$ blood group antigens to ensure that the techniques used were sufficiently sensitive for their detection.

Cervical mucus contained $\gamma$-globulin, $\beta$-globulin, transferrin and albumin, as reported by Moghissi, Neuhaus \& Stevenson (1960). Similar proteins were found in about half the samples of vaginal mucus examined by Anzai, Ibayashi, Aldrich \& Carpenter (1963). The slow $\gamma$-globulin in one sample of mucus obtained from the vagina, and which resembles the slow fragment of papaindigested $\gamma$-globulin, could not be analysed further to find out if it resulted from hydrolysis. Similar fragments having partial antigenic identity with $7 \mathrm{~S} \gamma$ globulins are found in Bence-Jones urinary proteins of myelomatosis (Cohen, 1963), and four different low molecular weight $\gamma$-globulins in normal urine (Fireman, Hershgold, Cordoba, Schmid \& Gitlin, 1964). They suggested that these are not degraded plasma proteins. There is therefore no evidence, yet, that globulins may be hydrolysed in the genital tract with a consequent decrease in their efficacy as antibodies.

The incidence of natural agglutinating anti- $\mathrm{A}$ and anti-B antibodies in mucus agrees closely with earlier reports (Gershowitz, Behrman \& Neel, 1958; Solish, Gershowitz \& Behrman, 1961).

There were six samples of cervical mucus that contained anti-A and anti-B antibodies with properties of the immune type. These haemolysins in cervical mucus were destroyed by 2-mercaptoethanol and the haemagglutinins partly inactivated. Most of this activity therefore appears due to $\operatorname{IgM}(19 S)$ antibodies.

More pertinent to this investigation was the failure of immune-type anti-A serum antibodies to have any deleterious effect on spermatozoa from group A secretor individuals, though they reacted with them. Human serum, with or without immune-type antibody, was harmless to the spermatozoa, unlike the sera of many other species, which are toxic to spermatozoa from the same species (Chang, 1947). We considered that immune-type antibody in women may have damaged the spermatozoa with the corresponding antigen, as a higher incidence of infertility and spontaneous abortion is reported in couples with an ABO incompatibility (Levine, 1943; Behrman, Beuttner-Janusch, Heglar, Gershowitz \& Tew, 1960; Wren \& Vos, 1961).

The immune anti-A antibody may have been too weak to damage the spermatozoa or was not the type needed to lyse nucleated cells, though group A erythrocytes were lysed. Another possibility is that antibody reacting with acquired antigens on the cell surface causes no damage. Spermatozoa acquire the A or B antigen from the seminal plasma if the man secretes either antigen (Edwards et al., 1964; Boettcher, 1965). This was confirmed and further demonstrated that spermatozoa from a group $\mathrm{A}$ non-secretor or a group $\mathrm{O}$ individual acquired the $\mathrm{A}$ antigen from the seminal plasma of an A secretor.

Seminal plasma, which contains several antigens (Rao \& Sadri, 1959) completely covers the surface of the spermatozoa (Weil \& Rodenburg, 1960). 
But antibodies detected by agglutination in the sera of women and some men are probably specific for these seminal plasma antigens and are probably harmless. Thus, Southam (1963) and Phadke \& Padukone (1964) found sperm agglutinins in the sera of fertile people. It is significant that sera of prostitutes and married women tested by the fluorescent antibody technique on frozen sections of testes, i.e. spermatozoa not coated by seminal plasma, revealed no specific antibody (Sutherland \& Landing, 1961).

The antibodies to acquired antigens on spermatozoa, though not cytotoxic, may nevertheless theoretically impede fertilization or development of an embryo by decreasing spermatozoal motility, or ability to fertilize the ovum or by preventing the early maturation of the zygote. At a later stage of pregnancy antibodies to blood group antigens might kill the foetus.

In this investigation cervical mucus from three women contained an antibody that immobilized, and in the presence of complement, lysed spermatozoa of any $\mathrm{ABO}$ blood group. It was specific for an antigen on the head of the spermatozoa and non-toxic for macrophages that had ingested the killed spermatozoa in the presence of the antibody. In the ultracentrifuge the antibody migrated in the 7S $\gamma$-globulin fraction. It was distinct from the antinuclear factor that reacts with nuclei of lymphocytes and human skin cells (Holborow, Weir \& Johnson, 1957) but not with heads of mature spermatozoa.

In women injected with human semen, the cervical secretions of about half of them were toxic for spermatozoa, though the sera of all of them were cytotoxic (Baskin, 1932; Escuder, 1936). The spermatozoa were agglutinated, immobilized or lysed by the cervical secretions in 5 to $15 \mathrm{~min}$, and less quickly by the serum. All the women were stated to be infertile as a result of the injections.

One object of the investigations was to test the possibility that antibody may be formed locally in the uterus, in the absence of systemic stimulation. Antibody against Trichomonas foetus is formed in the genital tract of cattle without being present in the blood stream, and the uterus may be sensitized passively resulting in a local anaphylactic reaction on instillation of the antigen (Kerr \& Robertson, 1953). The ejection of semen from cows shortly after service has also been considered to be allergic (Dawson, 1949). Further evidence of local antibody formation has been reviewed by Pierce (1959).

Straus (1961) found that subcutaneous injections of bacterial antigen in women resulted in the appearance of antibody in the vagina before the serum, but it did not persist. However, antigen applied to the vagina resulted in a persistent high agglutinin titre and the serum antibody level was usually less than that following injection.

Antibodies to several antigens apparently formed in the genital tract were found in the absence of the corresponding antibody in the serum during this investigation. Antibody was found in the cervical mucus but not in the serum in eleven women; in two it was immune-type anti-A and in one immune anti-B; in five it was antibody to the $\mathrm{H} 25$ flagella antigen of Escherichia coli and in three it was antibody cytotoxic for spermatozoa. It is not possible to determine whether the antibodies were formed in the mucosa of the uterus or in the cervix, but the cervix may have been one source of the antibody, since 
smears of cervical mucus from the three women with antibody to spermatozoa contained an unusually large number of plasma cells.

Immune-type anti-A and anti-B antibodies in the cervical mucus of group $\mathrm{O}$ women cannot be attributed to an antigenic stimulus by seminal plasma. It was not possible to make the necessary tests on the husbands; but substances with determinants of the $\mathrm{A}$ and $\mathrm{B}$ antigens are widely distributed in nature, including many bacteria (Race \& Sanger, 1962). Also, antibody to spermatozoa found in the sera of women (Southam, 1963; Franklin \& Dukes, 1964a, b) is not necessarily produced in the genital tract; antigen may be dispersed more widely by the lymphatic and vascular systems, and spermatozoa are capable of entering the peritoneal cavity from the Fallopian tubes (Horne \& Thibault, 1962).

Only a small proportion of women may form antibody cytotoxic to spermatozoa because the concentration of effective antigen may be low compared with the coating antigens from the seminal plasma. Moreover spermatozoal antigens may be less potent as they are homologous tissue antigens, though this does not prevent the formation of anti-leucocyte antibodies following multiple blood transfusions when the red cell antigens of the donors are compatible. The nucleoprotein of spermatozoa, though homologous tissue, has been considered to be an antigen in young adult women developing the antinuclear factor in lupus erythematosus (Lachmann, 1961). There is also the possibility that spontaneous allergy may occur even without previous exposure to semen. A rare case of anaphylactic sensitivity to a $\beta$-globulin of the seminal plasma has been investigated in detail by Halpern, Ky \& Robert (1964).

\section{ACKNOWLEDGMENTS}

This investigation was started at the Department of Pathology, Cambridge University, and Addenbrooke's Hospital, Cambridge.

For help in the collection of material we are very grateful to Mr R. L. Edwards with whom this investigation was started, Miss M. R. Glyn-John, Miss S. E. Flew and Mr C. Clennar. We are also grateful to Professor L. C. Ferguson and Dr R. R. A. Coombs for their kindness in sharing samples of semen which were used in their tests (Edwards et al., 1964).

We thank the M.R.C. Blood Group Genetics Laboratory, Lister Institute, for their great courtesy, particularly for the criticism of the manuscript by Dr Race, F.R.s., and Dr Sanger, and for the kind help of Miss June Gavin and Dr Patricia Tippett in tests on antibodies to the blood group antigens. We also thank Mr B. W. Gurner, for help with the mixed cell antiglobulin tests and the photography, Sister Joan Davies who provided the tonsils used to obtain macrophages, and Dr D. E. H. Tee for the loan of his fluorescent microscope.

\section{REFERENCES}

Anzai, T., Ibayashi, J., Aldrich, H. \& Carpenter, G. M. (1963) Immunochemical study of vaginal secretion. I. Detection of serum and non-serum protein components in normal vaginal secretion. Proc. Soc. exp. Biol. Med. 113, 54.

Baskin, M. J. (1932) Temporary sterilization by the injection of human spermatozoa. A preliminary report. Am. F. Obstet. Gynec. 24, 892. 
Behrman, S. J., Buettner-Janusch, J., Heglar, R., Gershowitz, H. \& Tew, W. L. (1960) ABO(H) blood incompatibility as a cause of infertility: a new concept. Am. F. Obstet. Gynec. 79, 847.

BoEtTcher, B. (1965) Human ABO blood group antigens on spermatozoa from secretors and nonsecretors. 7. Reprod. Fert. 9, 267.

Chalmers, D. G., Coombs, R. R. A., Gurner, B. W. \& Dausset, J. (1959) The mixed antiglobulin reaction in the detection of human iso-antibodies against leucocytes, platelets and HeLa cells. Brit. 7. Haemat. 5, 225.

Chang, M. C. (1947) The effects of serum on spermatozoa. F. gen. Physiol. 30, 321.

Cohen, S. (1963) $\gamma$-Globulin metabolism. Brit. med. Bull. 19, 202.

CRutckshank, B. \& Stuart-Smith, D. A. (1959) Orchitis associated with sperm-agglutinating antibodies. Lancet, i, 709 .

Dawson, F. L. M. (1949) Studies on catarrhal endometritis in the bovine, p. 71. Ph.D. thesis. University of Cambridge.

Edwards, R. G., Ferguson, L. C. \& Coombs, R. R. A. (1964) Blood group antigens on human spermatozoa. F. Reprod. Fert. 7, 153.

Escuder, C. J. (1936) La esterilización biológica temporaria de la mujer por esperma humano. Arch. Urug. Med. 8, 484.

Fireman, P., Hershgold, E., Cordoba, F., Schmid, K. \& Gituin, D. (1964) Low molecular weight $\gamma$ globulins of urine and plasma and their relation to 7S $\gamma 2$-globulin. Nature, Lond. $203,78$.

Franklin, R. R. \& Dukes, C. D. (1964a) Antispermatozoal antibody and unexplained infertility. Am. 7. Obstet. Gynec. 89, 6 .

Franklin, R. R. \& Dukes, C. D. (1964b) Further studies on sperm-agglutinating antibody and unexplained infertility. F. Am. med. Ass. 190, 682.

Gershowitz, H., Behrman, S. J. \& Neel, J. V. (1958) Hemagglutinins in uterine secretions. Science, $\mathcal{N} .{ }^{1} .128,719$.

Halpern, B., Ky, N. \& Robert, B. (1964) Etude immunologique d'un cas exceptionnel de sensibilisation spontanée au semen humain. C.r. hebd. Séanc. Acad. Sci., Paris, 259, 2025.

Hartmann, G. (1941) Group antigens in human organs, pp. 76-79. Munksgaards Forlag, Kobenhaven.

Holborow, E. J., WeIR, D. M. \& Johnson, G. D. (1957) A serum factor in lupus erythematosus with affinity for tissue nuclei. Brit. med. F. ii, 732.

Horne, H. W. \& Thibault, J.-P. (1962) Sperm migration through the human female reproductive tract. Fert. Steril. 13, 135.

KerR, W. R. \& Robertson, M. (1953) Active and passive sensitization of the uterus of the cow in vivo against Trichomonas foetus antigen and the evidence for the local production of antibody at that site. F. Hyg., Camb. 51, 405.

Lachmann, P. J. (1961) An attempt to characterize the lupus erythematosus cell antigen. Immunology, 4, 153.

LEvine, P. (1943) Serological factors as possible causes in spontaneous abortions. 7. Hered. 34, 71.

Moghissi, K., Neuhaus, O. W. \& Stevenson, C. S. (1960) Composition and properties of human cervical mucus. I. Electrophoretic separation and identification of proteins. $\mathcal{F}$. clin. Invest. 39, 1358.

Molurson, P. L. (1961) Blood transfusion in clinical medicine, 3rd edn., pp. 267, 272 and 597. Blackwell Scientific Publications, Oxford.

Nakabayashi, N. T., Tyler, E. T. \& Tyler, A. (1961) Immunologic aspects of human infertility. Fert. Steril. 12, 544.

Phadke, A. M. \& Padukone, K. (1964) Presence and significance of auto-antibodies against spermatozoa in the blood of men with obstructed vas deferens. F. Reprod. Fert. 7, 163.

Pierce, A. E. (1959) Specific antibodies at mucous surfaces. Vet. Rev. Annotat. 5, 17.

RAce, R. R. \& SANGeR, R. (1962) Blood groups in man, 4th edn, pp. 38-40 and 44. Blackwell Scientific Publications, Oxford.

RAo, S. S. \& SADRI, K. K. (1959) Immunological studies with human semen and cervical mucus. VIth International Conference on Planned Parenthood, New Delhi, p. 313.

Rodriquez-López, M. B. (1936) Esterilización biológica temporaria de la mujer. Arch. Urug. Med. 9, 373.

Rümke, Ph. \& Hellivga, G. (1959) Autoantibodies against spermatozoa in sterile men. Am. F. clin. Path. 32, 357.

Solish, G. I., Gershowitz, H. \& Behrman, S. J. (1961) Occurrence and titre of isohemagglutinins in secretions of the human uterine cervix. Proc. Soc. exp. Biol. Med. 108, 645.

Southam, A. L. (1963) Clinical significance of antibodies to spermatozoa and seminal plasma. $\mathcal{J}$. Reprod. Fert. 5, 458.

Straus, E. K. (1961) Occurrence of antibody in human vaginal mucus. Proc. Soc. exp. Biol. Med. 106, 617.

Sutherland, J. M. \& Landing, B. H. (1961) Failure to demonstrate antibody to sperm in serum of prostitutes. Lancet, $\mathbf{i i}, 56$. 
TYLER, A. (1961) Approaches to the control of fertility based on immunological phenomena. F. Reprod. Fert. 2, 473.

Weil, A. J. \& Rodenburg, J. M. (1960) Immunological differentiation of human testicular (spermatocele) and seminal spermatozoa. Proc. Soc. exp. Biol. Med. 105, 43.

WREN, B. G. \& Vos, G. H. (1961) Blood group incompatibility as a cause of spontaneous abortion. $\mathcal{J}$. Obstet. Gynaec. Br. Cmwlth, 68, 637. 